\title{
Integration of adsorption chillers with combined cycle gas turbine
}

\author{
Karol Sztekler ${ }^{1}{ }^{*}$, Wojciech Kalawa ${ }^{1,}$ Lukasz Mika ${ }^{1}$,Jarosław Krzywanski ${ }^{2}$, Karolina Grabowska $^{2}$, Marcin \\ Sosnowski ${ }^{2}$, Lukasz Lis ${ }^{1}$, Wojciech Nowak ${ }^{1}$, Artur Eukasz Lis ${ }^{1}$, Tomasz Siwek ${ }^{1}$ \\ ${ }^{1}$ AGH University of Science and Technology, Faculty of Energy and Fuels; A. Mickiewicza 30, 30-059 Cracow, Poland \\ ${ }^{2}$ Jan Dlugosz University in Czestochowa; Faculty of Mathematics and Natural Sciences, Armii Krajowej 13/15, 42-200 \\ Czestochowa, Poland
}

\begin{abstract}
More efficient use of the primary energy contained in fuels translates into tangible earnings for power plants while reductions in the amounts of fuel burned, and of non-renewable resources in particular, certainly have a favourable impact on the natural environment. The main aim of the paper is to investigate the contribution of the use of adsorption chillers to improve the production energy efficiency in combined cycle gas turbine. Simulation calculations were performed using Sim tech's IPSEPro software.
\end{abstract}

\section{NOMENCLATURE}

Subscripts

Ads - adsorber

$\mathrm{c}$ - calculated

cond - condenser

des - desorber

evap - evaporator

sorb - sorbent

Greek symbols

Acronyms

AC - Adsorption Chiller

Fuzzy Inference System

$\mathrm{CC}$ - Cooling Capacity

CCHP - Combined Cooling, Heating and Power

COP - Coefficient of performance

SCP - Specific cooling power

HVAC - Heating, Ventilation, Air Conditioning

\section{Introduction}

Refrigeration has also found its application in various industry branches, from food production and storage, through the pharmaceutical industry, to heavy industry and power generation. Between 2015 and 2019, the HVAC market in Poland saw an increase of $3.5 \%$ to even $6.5 \%$ annually [10]. Since the $1980 \mathrm{~s}$, there has been a continuous increase in the number of air-conditioning systems in buildings in the European Union. In recent years power consumption has been stable at around $155 \mathrm{TWh}$ annually but this is due to improved efficiency and environmental performance of the devices rather than a decreasing trend in the use of air conditioners [11]. Even today, the growing requirement for cooling hugely contributes to demand on electrical grids in many countries. In 2016, it accounted, on average, for approx. $14 \%$ of the peak demand, and much more in some regions of the world. In the USA and the Middle East air conditioning accounts for over $70 \%$ of peak electricity demand on extremely hot days. It is expected that power consumption for cooling will differ from the trend concerning heating [9].
The use of fossil fuels implies a lot of adverse effects for the environment, such as global warming, acid rains, smog, soil contamination and water pollution. Furthermore, world energy resources are dwindling. One of the methods of increasing the effectiveness of the utilisation of chemical energy from fuels while at the same time reducing the adverse impact on the environment is by polygeneration systems where electricity is generated together with heat and cooling.

\section{Analysis and modeling}

The basic adsorption unit must consist of three components, i.e. an adsorbent bed, a condenser and an evaporator. One operating cycle of the device is made up of four stages, in like manner as in an absorption chiller. These are heating and increasing pressure in the bed; desorption (also called bed regeneration); cooling and reducing pressure in the bed; and adsorption.

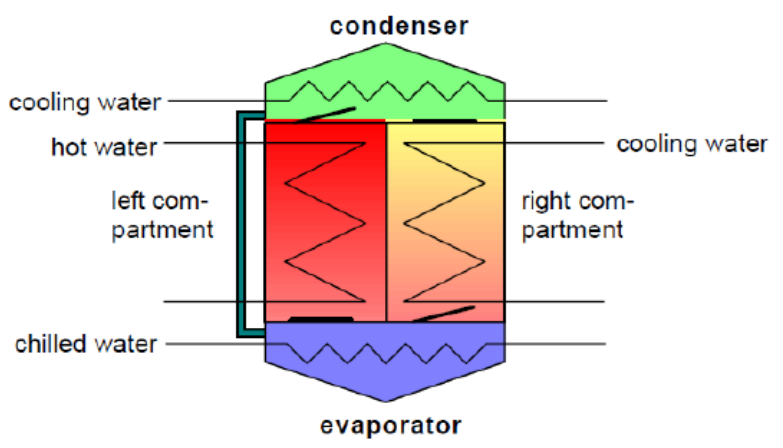

Fig 1. Adsorption cooling system Errore. L'origine riferimento non è stata trovata.

Adsorption chillers are characterised by reduced demand for electricity, which is due to the lack of compressor pumps in the device intended to force the operating medium to flow in the circulation system. Electric power is only used to control the automatic functions. Adsorption chillers 
are characterised by a simple design without any moving parts, pumps or compressors; they are quiet and do not generate any vibrations, operation of an adsorption chiller based on the silica-gel-water working is possible from approx. $43^{\circ} \mathrm{C}$. Their operating cost is much lower as compared with other types of chillers; they have a long lifetime and are not dependent on power supply. Adsorption chillers also have some disadvantages including their large dimensions and mass, considerable development costs or high design requirements due to the necessity of maintaining very low pressures $[1,2,3,4,12,13,14,15]$. This analysis concerns the impact of an adsorption chiller on a gas and steam cycle utilising a gas turbine is Siemens SGT54000F [11].

The basic parameters of the gas and steam CHP unit have been presented in Table 1 .

Table 1. Basic parameters of the gas and steam cycle

\begin{tabular}{|c|c|}
\hline Electric power output & $383.28 \mathrm{MWe}$ \\
\hline Thermal power output & $343.93 \mathrm{MWt}$ \\
\hline Useful heat Qun & $251.44 \mathrm{MWt}$ \\
\hline Electrical efficiency & $51.7 \%$ \\
\hline Steam mass flow & $70 \mathrm{~kg} / \mathrm{s}$ \\
\hline
\end{tabular}

The gas and steam cycle with a back pressure turbine has some limitations related to operation in the summer season. If this type of turbine is used, then the electricity generation is strictly dependent on generation of heat for end consumers. In the event of reduced demand for heat electricity generation is also reduced, which affects the costs related to the operation of the whole generation system. Based on available literature data [5], heat generation is reduced in the summer season even by $80 \%$ compared with the winter season.

Municipal consumers usually receive district heat in hot water whose temperature increases in winter to $130-150^{\circ} \mathrm{C}$ depending on the outside temperature; in summer it is approx. $70^{\circ} \mathrm{C}[5,6]$. District heat can also be used to generate cooling. For this purpose, chillers fed with hot water, such as adsorption chillers, are used. This way, three types of energy, i.e. electricity, heat and heating, can be generated in one process; cogeneration turns then into trigeneration.

The optimal solution in such a case will be utilisation of an adsorption chiller based on the silica-gel/water pair. A good example of such a device can be a chiller from the company NEW ENERGY TRANSFER with a power output of 1.2 MW. This device is capable of operating at feed temperatures in the range from $60^{\circ} \mathrm{C}$ to $84^{\circ} \mathrm{C}$, producing chilled water with a temperature of $11^{\circ} \mathrm{C}$. The drop in the temperature of the water fed to the chiller is $\Delta \mathrm{T}_{\mathrm{z}}=7^{\circ} \mathrm{C}$. [7]
Table 2. Operating parameters of a CHP unit with an adsorption chiller

\begin{tabular}{|c|c|c|c|}
\hline Name of parameter & Symbol & Value & Unit \\
\hline $\begin{array}{c}\text { CHP electric power } \\
\text { output }\end{array}$ & $\mathrm{Nen}_{\mathrm{en}}$ & 383.28 & $\mathrm{MW}$ \\
\hline $\begin{array}{c}\text { Chemical energy } \\
\text { utilisation factor in } \\
\text { cogeneration }\end{array}$ & $\mathrm{EUF}_{\mathrm{t}}$ & 85.74 & $\%$ \\
\hline $\begin{array}{c}\text { Chemical energy } \\
\text { utilisation factor in } \\
\text { trigeneration } \\
{[6]}\end{array}$ & $\mathrm{EUF}_{\mathrm{t}}$ & 75.56 & $\%$ \\
\hline $\begin{array}{c}\text { Maximum cooling } \\
\text { capacity }\end{array}$ & Qch & 112.8 & $\mathrm{MW}$ \\
\hline
\end{tabular}

In the analysed case it was assumed that electricity generation is at the maximum performance, i.e. there is no difference in electricity generation between the summer and winter seasons. This decrease chemical energy in the factor is mainly the result of the low cooling capacity coefficient for adsorption chillers. However, despite the reduced chemical efficiency indicator, this system allows for electricity generation be maintained at a constant level with simultaneous generation of cooling and heat.

\section{Summary}

For gas and steam cycles with a back pressure turbine, it is important to ensure constant heat transfer at the cycle exchangers which fulfil the function of evaporators. In the summer season there is reduced demand for heat, which results with reduced heat transfer from the exchangers and contributes to the reduction of electricity generation in the steam cycle. The adsorption chiller provides a solution in the situation of reduced demand for heat generation in the summer season As a result of the operation of the chilling device cooling is generated at 112.8 MW which cooling can be used for air conditioning or as process heat. Polygeneration cycles with adsorption chillers provide an ideal solution aimed at ensuring constant electricity generation in the summer season thus maximising utilisation of the chemical fuel energy.

\section{REFERENCES}

1. R. P. Sah, B. Choudhury, R.K. Das, Renew. Sustain. Energy Rev., 45, pp. 123134 (2015)

2. A. N. Shmroukh, A.H. H. Ali, S. Ookawara, Renew. Sustain. Energy Rev., 50, pp. 445-456 (2015)

3. J. Krzywanski, K. Grabowska, F. Herman, P. Pyrka,M. Sosnowski, T. Prauzner, W. Nowak, Energy Conversion and Management, 153, pp. 313-322 (2017) 
4. M.Z.I. Khan, K.C.A Alam, B. Saha, A. Akisawa, T. Kashiwagi, Applied Thermal Engineering, 27, pp.1677-1685 (2007)

5. https://termika.pgnig.pl/elektrocieplowniazeran

6. J. Skorek, J. Kalina, Gas cogeneration system (2005)

7. http://newenergytransfer.com/

8. International Energy Agency, The Future of Cooling Opportunities for energyefficient air conditioning, International Energy Agency (2018)

9. https://biznes.newseria.pl/biuroprasowe/ochrona_srodowiska/wzrostrynku-hvac-spowolni,b922159909

10. https://wysokienapiecie.pl/10243klimatyzacja-potrzebuje-coraz-wiecejenergii/

11. https://new.siemens.com/global/en/product s/energy/power-generation/gasturbines/sgt5-4000f.html

12. J. Krzywanski, K. Grabowska, M. Sosnowski, A. Żyłka, K. Sztekler, W. Kalawa, T. Wójcik, and W. Nowak, MATEC Web of Conferences 240, 05014 (2018)

13. J. Krzywanski, K. Grabowska, M. Sosnowski, A. Zylka, K. Sztekler, W. Kalawa, T. Wojcik, and W. Nowak, Thermal Science 23, 1053 (2019)

14. K. Grabowska, M. Sosnowski, J. Krzywanski, K. Sztekler, W. Kalawa, A. Zylka, and W. Nowak, Journal of Thermal Science 27, 421 (2018)

15. K. Grabowska, M. Sosnowski, J. Krzywanski, K. Sztekler, W. Kalawa, A. Zylka, and W. Nowak, MATEC Web Conf. 240, 01010 (2018) 